\title{
Childhood Lung Small Cell Carcinoma
}

National Cancer Institute

\section{Source}

National Cancer Institute. Childhood Lung Small Cell Carcinoma. NCI Thesaurus. Code

C118815.

A rare small cell carcinoma of the lung that occurs during childhood. 